\title{
Urban Marketing and its Impact over the Touristic Attractiveness of the Cities - A Conceptual Approach
}

\author{
Elena Lidia Alexa, „Al. I. Cuza” University of Iasi, Romania
}

\begin{abstract}
Considering the current issues the urban centers are dealing with, the amplified city competitiveness and the increased demand of qualitative public services, it appears the need to apply new urban management approaches, more oriented toward the market and the current needs of the city.

The competitive environment pressure creates the need to pass from an entirely administrative approach to a more managerial one, in all aspects regarding the current problems of the cities. Thus, the urban stakeholders borrow more and more often working methods and techniques specific until now only for the private sector, in order to increase the public service's performance and to sustainable develop their community. Urban marketing came as a natural response to the cities needs to bring added value to their urban management strategies.

The final objective is to increase the cities attractiveness for different target groups: starting with the current and future inhabitants, continuing with tourists and finishing with potential investors, which by relocating their business, could become a part of the faster and more sustainable urban development.
\end{abstract}

\section{Keywords}

urban marketing, destination marketing, city branding, tourism, touristic attractiveness, competitiveness.

\section{JEL Codes: M 31, L83}

\section{Introduction}

In the globalization era, characterized by profound political and economical reforms of which main objective is the increased competitiveness, whether we talk about goods, companies, cities or countries, the proactive attitude and an integrated marketing strategy are a must in order to survive and to develop.

Now more than ever, cities have become brands of their one, because they are in an endless competition for attention, investments, inhabitants and tourists and the main competitor is no longer the city located a couple of kilometers away, but any city across the globe.

Tourism is a huge potential and a challenge for urban managers which have to find and assimilate marketing strategies meant to allow the development of touristic functions and of touristic programs designed to bring added value to the cultural attractions for large and small cities alike.

Cities and regions need competitive strategies in order to attract more tourists, investors and inhabitants and for this they have to make a change in the decision makers' attitude. The new city is no longer a plain urban conglomerate; it becomes a Company, a Product, and a Market depending on the target group it applies to. 


\section{Destination Marketing}

In the marketing literature, there are two theoretical approaches regarding destination marketing: one concentrates over the successful strategies applied by different entities, while the other one underlines the connection between destination branding and the aspects regarding the impact of the economical and political factors and the effect of the business stakeholder's involvement over the communities' development ${ }^{1}$.

Although the destination marketing concept is not a new notion, it became more popular in the literature in the 80s, once the cities became more aware of the importance of marketing and promotion impact over their development. Thus, destination marketing has many definitions. For example, according to Gold and Ward, destination marketing is defined as the conscientious use of marketing and publicity in order to communicate selective images of various areas and cities among different target ${ }^{2}$. The definition focuses on the idea of selecting certain images to be promoted, images and aspects which are meant to increase destinations' attractiveness; this opinion led to criticism in the marketing literature, most authors questioning whether not this definition refers to the possibility of ignoring or hiding the destination's negative aspects.

The concept of "destination branding" has been extensively explored. After summarizing the evolution of destination branding definitions, Blain, Levy and Ritchie (2005) developed a revised definition that incorporated earlier efforts: destination branding is the set of marketing activities that (1) support the creation of a name, symbol, logo, word mark or other graphic that readily identifies and differentiates a destination; that (2) consistently convey the expectation of a memorable travel experience that is uniquely associated with the destination; that (3) serve to consolidate and reinforce the emotional connection between the visitor and the destination; and that (4) reduce consumer search costs and perceived risk. Collectively, these activities serve to create a destination image that positively influences consumer's destination choice ${ }^{3}$.

Branding is therefore considered mutually beneficial from both the supply and demand perspectives.

The brand's ability to differentiate effectively can generate advantages for products and services, such as increased purchase intent ${ }^{4}$, lower $\operatorname{costs}^{5}$, increased sales, price premiums and customer loyalty ${ }^{6}$.

Among the destination's advantages are: increased potential to differentiate against places offering similar benefits, increased destination loyalty and increased yield for stakeholders such as local tourism businesses and travel intermediaries. The benefits for travelers include ease of decision making through reduced search costs, reduced perceived risks and possibly the guarantee for an improved experience.

In destinations' case, differentiation is extremely important, giving the fact that the tourism market is the fastest growing economic market, which leads to an increased, more aggressive competition, especially since most destinations offer similar benefits which makes them easily interchangeably. For example, $70 \%$ of the international tourists visit only 10 countries,

\footnotetext{
${ }^{1}$ Bradley, A, Hall, T., Harrison, M. (2002), “Selling cities: Promoting new images for meetings tourism”, Cities, 19(1), pp. 61-70.

${ }^{2}$ Gold, JR., Ward, SV. (eds.) (1994), Place promotion: The use of publicity and marketing to sell towns and regions, John Wiley \& Sons, Chichester.

${ }^{3}$ Blain, C., Levy, S., Ritchie, J.R.B. (2005), “Destination Branding: Insights and Practices”, Destination Management Organizations Journal of Travel Research, Vol. 43, No. 4, 2005, pp. 328-338.

${ }^{4}$ Cobb - Walgren, C. J., Beal, C., Donthu, N. (1995), "Brand equity, brand preferences, and purchase intent”, Journal of Advertising, 24(3), 1995, pp. 25-40.

${ }^{5}$ Keller, K. L., “Conceptualizing, measuring, and managing customerbased brand equity”, Journal of Marketing, 57, 1993, pp.1-22.

${ }^{6}$ Aaker, D. A. (1996), Building strong brands, Free Press, New York.
} 
which means that the rest of the tourist destinations compete for $30 \%$ of the international arrivals ${ }^{7}$.

\section{Urban Marketing}

The extensive urbanization led to the endorsement of the urban marketing concept; after 1990 the term begun to be widely used because of the increased competition between cities eager to attract more tourists, inhabitants, potential investors, all these things leading to a better living standard.

The globalization had a direct impact over the public sector which is now required to reinvent itself and to apply strategies and methods which were until now, distinctive for the private sector.

More experienced in this area, the United States and several Western European Countries applied urban marketing in their regional and local strategies and published their experiences as "best practice" models in order that other organizations use it too. Among the urban centers that have an adjusted urban marketing system are: New York, Paris, Barcelona, Vienna, Berlin, Amsterdam etc.

Thus, in Corsico's opinion, urban marketing is the alignment of the urban politics to the requirements of the local economic stakeholders and to the hopes and expectations of those operating outside of it, in order to better promote the local economy ${ }^{8}$.

Another marketing specialist, Jan van der Meer, considers that urban marketing can be described as a set of activities directed to enhance the correlation between the urban functionalities offer and the demand from its inhabitants, local companies, tourists and other visitors $^{9}$.

The marketing literature focuses on underlining the importance of city development and constant promotion of its elements, the increased competitiveness being an indirect effect of the applied strategies. Urban marketing must be designed as a general principle focused on city development, thus, on problems regarding housing, jobs, communications, facilities, environment. It is also characterized by a planning process including all stages of task allocation, current situation, strengths and weaknesses analysis, definition of its' own level of competitiveness and implementing, monitoring and evaluating the activities. All these must lead to a concurring vision over the city and tasks for all the stakeholders involved in the process. The development based on local potential, significant projects, joint activities and the enhanced image as a whole must represent the goal achieved through the urban marketing process ${ }^{10}$.

In essence, urban marketing implies: to project the adequate combination of community characteristics and services, to establish attractive incentives for current and potential buyers, to create and efficient and accessible products and services delivery system inside the city, to promote the city's values and the image, so that the potential buyers will be aware of the distinctive advantages of the place.

Thus, the perception over the cities and their image in the collective mind has become an important active component in their economic success or failure of their development.

\footnotetext{
${ }^{7}$ Morgan, N., Pritchard, A., Pride, R. (2004), Destination branding - Creating the unique destination proposition, 2nd Edition, Butterworth-Heinemann, Oxford.

${ }^{8}$ Corsico, F. (1994), "Urban Marketing, a Tool for Cities and for Business Enterprises, a Condition for Property Development, a Challenge for Urban Planning”, Urban Marketing in Europe - International Conference, Ave, G. and Corsico; f. (eds.), Torino Incontra, Torino.

${ }^{9}$ Meer, van der Jan (1992), The role of urban marketing in the urban management, The European Institute for Urban Comparative Studies, Erasmus University, Rotterdam.

${ }^{10}$ Koster, A. (1994), "Urban Marketing - A new Approach for Town Planning and a Chance for Reactivation of Sites in Old-Industrial Regions”, Urban Marketing in Europe - International Conference, Torino Incontra, Torino.
} 
The leaders of different countries, regions, cities begun to realize that a positive image combined with a successful marketing mix is a powerful instrument in the competition for resources and other economic activities. The cities' management system suffered a change for the better by introducing some elements regarding commercials, public relations, direct marketing and sales promotions ${ }^{11}$.

A key element in urban marketing refers to the difficulty of defining the city's identity and values in a way that can be widely accepted and easily marketed for all target groups. The challenge is given by the need to create a common identity from values that are not always intangible and which represent the interests of different social and economic groups. City branding must determine how culture, history, economic growth, social development, infrastructure, architecture, landscape and environment, among other components, can be combined in an identity later to be "sold"

In this process, the decision maker's role is crucial, and in order for the urban marketing to succeed, a long term vision, both from the marketing and management point of view, is needed $^{13}$.

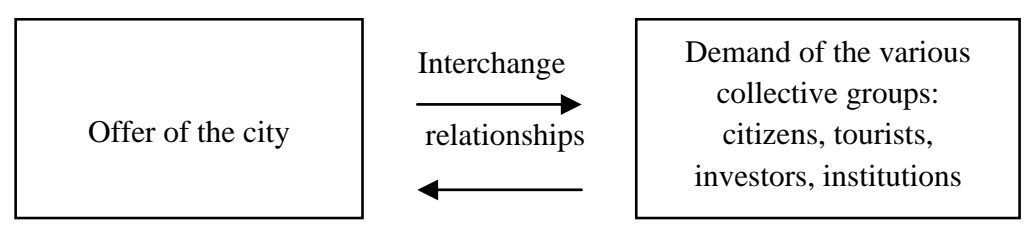

Figure. 1. Interchange relationships between the city and the collective groups

\section{Urban Tourism}

According to the World Tourism Organization (UNWTO), tourism is firmly established as the number one industry in many countries and the fastest-growing economic sector in terms of foreign exchange earnings and job creation.

Specialized literature does not provide a widely accepted definition for urban tourism. However, there are common elements among different authors regarding the concept of tourist, excursionist and the delimitation of the urban area. Thus, it is widely accepted that urban tourism refers both to the movement of tourists in cities or urban agglomerations of at least 20.000 people outside their main residence, under the condition of remaining at least one night at the destination and to the tourist travel for at least 24 hours in the urban area, provided that the minimum travel distance is at least $100 \mathrm{~km}^{14}$.

World Tourism Organization considers that urban tourism refers to travels inside cities or areas with a high population density ${ }^{15}$.

If until recently urban tourism was seen as a result of population mobility, for which the city was only a brief stopover on the way to the final destination, at present, due to significant tourism consumer behavioral changes and to extensive changes in the urban management, the city turned into a cultural center, a relaxing place where people shop, meet with friends

\footnotetext{
${ }^{11}$ Avraham, Eli, Daniel, Daugherty (2009), “We're known for oil. But we also have watercolors, acrylics \& pastels: Media strategies for marketing small cities and towns in Texas” - Cities, 26, pp. 331-338.

${ }^{12}$ Zhang, Li, Simon, Zhao (2009), "City branding and the Olympic effect: A case study of Beijing”, Cities, 26, pp. 245-254.

${ }^{13}$ d'Angella, Francesca, Go, M., Frank (2009), “Tale of two cities' collaborative tourism marketing: Towards a theory of destination stakeholder assessment”, Tourism Management, 30, pp. 429-440.

${ }^{14}$ G. Cazes, Fr. Potier (1996), Le tourisme urbain, PUF, Paris, p. 10.

${ }^{15}$ UNWTO, Tourism 2020 Vision, Volume 7, Global Forecasts and Profiles of Market Segments, p. 103.
} 
and spend their free time pleasantly. Therefore, one can say that urban tourism is not just a form of tourism, but an integral part, a traditional and distinctive feature of the urban life ${ }^{16}$. The importance of urban tourism is underlined by the fact that in 1991 was created ECT European Cities Tourism which is the European association of the urban tourism organizations (former Federation of European Cities' Tourist Offices - FECTO) with the overall aim to strengthen city tourism in Europe.

The purpose of ECT is sharing information and knowledge among its members, building opportunities of joint-marketing activities for European cities, and representing city tourism industry interests in EU meetings.

According to IPK International ${ }^{17}$ consulting company, urban tourism is one of the most dynamic forms of tourism. For example, in 2005 over 2004, city breaks segment increased by $20 \%$ compared with only $3 \%$ for seaside tourism, $8 \%$ summer mountain tourism and $12 \%$ winter mountain tourism, and the trend is expected to continue in the following years. Currently, tourist short term visits in the cities (city breaks) hold a share of $38 \%$ of all international travels by Europeans, the percentages varying from one country to another.

It is estimated that approximately $80 \%$ of visits in cities represents pure urban tourism (the motivation is exclusive) and $20 \%$ is complementary tourism - visiting urban settlements are associated with other forms of holiday spending (seaside, mountains, rural areas, circuits, etc.).

The origin and development of this form of tourism is mainly motivated by the change in the tourism purchasing behavior through the fragmentation of holidays, the population revenue growth, the changed motivations for traveling determined by the increased educational level, the bigger demand for business tourism, the amplified mobility, determined by the diversification of transport options.

The city break market is currently concentrated on a relatively small number of cities and is fiercely competitive. Paris and Amsterdam are the most popular destinations, with additional European competition coming from Rome, Brussels, Barcelona, Venice, Prague, London, and Dublin. Long haul destinations are also attracting a growing number of visitors. New York is by far the most popular long haul destination. ${ }^{18}$

The global economic crisis has been strongly associated with a tendency to take holidays at home or in a neighborly country which has a significant impact over the urban tourism market. This trend is widely reported across Europe with many local variations. Generally, however, it is more intense in Northern and Western Europe than in Central and Eastern Europe, where the local economies have been sometimes so badly affected that even local travel has been curtailed. This may help to explain some of the renewed declines reported in recent months in Central and Eastern Europe, which are neither close enough to Western European markets to count as local, nor prosperous enough to benefit from domestic and cross-border tourism ${ }^{19}$.

This overall trend can be counteracted through a more aggressive urban destinations marketing and through restructuring the touristic packages, in order to better adjust them to the needs and requests of the tourism buyers.

\section{Conclusions}

Tourism is a huge potential and challenge for development of cities. It provides financial resources for the restoration of old buildings and the creation of general infrastructure that

\footnotetext{
${ }^{16}$ Frank, Howie (2003), Managing tourist destinations, Thomson Learning EMEA, p. 93.

17 *** IPK International, ITB Convention Market, Trends and Innovations, 9 January 2006.

18 ***Urban Tourism and Dispersal, Produced for the Enterprise \& Lifelong Learning Committee, The Scottish Parliament, 12 August 2002.

19 ***Europe Tourism 2009 - Trends and prospects, Quarterly Report Q4/2009, European Travel Commission.
} 
can be used by the local population. Through tourism the cultural resources of a place are exploited, assuring, in the same time financial resources for developing other facilities, which, in the end lead to an increased quality of life for the inhabitants.

After analyzing the main indicators of the touristic activity in the urban area, it is noticeable that cities have an important percentage in the overall touristic circulation. The future development of this form of tourism is, however, conditioned by the assimilation in the urban management process of marketing strategies meant to allow the development of touristic functions in the main urban localities and of touristic programs designed to bring added value to the cultural attractions for large and small cities alike.

Urban marketing comes, in this case, as a natural response to the requirements of the city to better answer the market's needs and to adjust to the dynamics of the tourism industry.

\section{References}

1. Aaker, D. A. (1996), Building strong brands, Free Press, New York.

2. Avraham, Eli, Daniel, Daugherty (2009), "We're known for oil. But we also have watercolors, acrylics \& pastels”: Media strategies for marketing small cities and towns in Texas” - Cities, 26, pp. 331-338.

3. Blain, C., S. Levy, J.R.B., Ritchie (2005), "Destination Branding: Insights and Practices”, Destination Management Organizations Journal of Travel Research, 43(4), pp. 328-338.

4. Bradley, A, Hall, T., Harrison, M. (2002), "Selling cities: Promoting new images for meetings tourism”, Cities, 19(1), pp. 61-70.

5. Cazes, G. Potier Fr. (1996), Le tourisme urbain, PUF, Paris.

6. Cobb - Walgren, C. J., Beal, C., Donthu, N. (1995), "Brand equity, brand preferences, and purchase intent”, Journal of Advertising, 24(3), pp. 25-40.

7. Corsico, F. (1994), "Urban Marketing, a Tool for Cities and for Business Enterprises, a Condition for Property Development, a Challenge for Urban Planning”, Urban Marketing in Europe International Conference, Ave, G. and Corsico; f. (eds.), Torino Incontra, Torino

8. d'Angella, Francesca, Go, M., Frank, Tale of two cities' collaborative tourism marketing: Towards a theory of destination stakeholder assessment, Tourism Management, nr. 30, 2009, pp. 429-440.

9. Gold, JR., SV. Ward, (eds.) (1994), Place promotion: The use of publicity and marketing to sell towns and regions, John Wiley \& Sons, Chichester.

10. Howie, Frank, (2003), Managing tourist destinations, Thomson Learning EMEA.

11. Keller, K. L. (1993), “Conceptualizing, measuring, and managing customerbased brand equity”, Journal of Marketing, 57, pp.1-22.

12. Koster, A. (1994), „Urban Marketing - A new Approach for Town Planning and a Chance for Reactivation of Sites in Old-Industrial Regions”, Urban Marketing in Europe - International Conference, Torino Incontra, Torino.

13. Meer, van der Jan (1992), The role of urban marketing in the urban management, The European Institute for Urban Comparative Studies, Erasmus University, Rotterdam.

14. Morgan, N., A. Pritchard, R. Pride, (2004), Destination branding - Creating the unique destination proposition, 2nd Edition, Butterworth-Heinemann, Oxford.

15. Zhang, Li, Simon, Zhao (2009), „City branding and the Olympic effect: A case study of Beijing”, Cities, 26, 2009, pp. 245-254.

16. ***Europe Tourism 2009 - Trends and prospects, Quarterly Report Q4/2009, European Travel Commission

17. ***IPK International, ITB Convention Market, Trends and Innovations, 9 January 2006.

18. ***Urban Tourism and Dispersal, Produced for the Enterprise \& Lifelong Learning Committee, The Scottish Parliament, 12 August 2002.

19. ***UNWTO, Tourism 2020 Vision, Volume 7, Global Forecasts and Profiles of Market Segments, p. 103. 